\title{
OURO DE TOLO, UMA EPOPEIA DA DESILUSÃO - O PÃO, O CIRCO E O TRANSCENDENTE: DIÁLOGO ENTRE RAUL SEIXAS E FRIEDRICH NIETZSCHE
}

\author{
OURO DE TOLO (FOOL'S GOLD), A DISILLUSIONMENT'S EPIC SAGA - THE \\ BREAD, THE CIRCUS AND THE TRANSCENDENTAL: DIALOG BETWEEN RAUL \\ SEIXAS AND FRIEDRICH NIETZSCHE
}

\author{
Fernando Bruno Antonelli Molina Benites' \\ Guilherme Primo de Mendonça ${ }^{2}$ \\ Mauricio Cesar Menon ${ }^{3}$
}

\begin{abstract}
Resumo: O objetivo deste estudo é realizar uma leitura da letra da canção Ouro de tolo (1973), de Raul Seixas, considerando alguns dos mais contundentes e célebres aforismos de Friedrich Nietzsche, compilados por Allan Percy (2011). Intrigados com os versos carregados de pretensas conquistas pessoais, cantados em tom lamurioso, os autores empreenderam um estudo que pudesse analisar, dialogicamente, a canção e o pensamento do polêmico filósofo, que quase um século antes assumira seu ateísmo ao mesmo tempo em que se desiludira com um mundo sem a presença de Deus. Levando em consideração os trabalhos de Roszak (1972), Carmo (2000) e Calvani (1998) buscaram também compreender as influências - individual e compartilhada - de ambos na Contracultura e sua relação hostil com o sistema vigente, denunciando as falsas conquistas e alertando para uma realidade ideal que meça a felicidade dentro de outra escala, atentando para o valor que deve ser atribuído ao imaterial e trancendente. Por fim, recorreram a Tatit (1997), no ensejo de melhor compreender a associação entre versos e máximas embalados pela harmonia e cadência, bem como a outras obras de Nietzsche e Raul Seixas que pudessem confirmar as digressões aqui propostas.
\end{abstract}

Palavras-chave: Ouro de tolo; contracultura; pão e circo; pessimismo; autoconhecimento.

Abstract: The aim of this study is to perform a reading of Raul Seixas's Ouro de tolo (1973) song lyrics, considering some of Friedrich Nietzsche's most overwhelming and well-known aphorisms, compiled by Allan Percy (2011). Intrigued by the verses filled with pretended personal achievements sung in a whining tone, the authors undertook a study that could analyze dialogically the song and the thought of the controversial philosopher, who almost a century before had assumed his atheism at the same time that he had been disillusioned with a world without the presence of God. Considering the works of Roszak (1972), Carmo (2000) and Calvani (1998), they also sought to understand the individual and shared influences of both in the Counterculture and their hostile relationship with the current system, denouncing the false achievements and alerting for an ideal reality that measures happiness within another scale, paying attention to the value that must be attributed to the immaterial and transcendent. Finally, they turned to Tatit (1997) in order to better understand the association between verses and adages lulled by harmony and cadence, as well as to other works by Nietzsche and Raul Seixas that could confirm the digressions proposed here.

Keywords: Ouro de tolo; counterculture; bread and circus; pessimism; self-knowledge.

\footnotetext{
1 Mestrando no Programa de Pós-Graduação Stricto Sensu em Ensino de Ciências Humanas, Sociais e da Natureza - Universidade Tecnológica Federal do Paraná - UTFPR, PR, Brasil. E-mail: professorfernandobruno@gmail.com.

2 Mestrando no Programa de Pós-Graduação Stricto Sensu em Ensino de Ciências Humanas, Sociais e da Natureza - Universidade Tecnológica Federal do Paraná - UTFPR, PR, Brasil. E-mail: guiprimo@hotmail.com.

${ }^{3}$ Docente no Programa de Pós-Graduação Stricto Sensu em Ensino de Ciências Humanas, Sociais e da Natureza - Universidade Tecnológica Federal do Paraná - UTFPR, PR, Brasil. E-mail: mcmenon@utfpr.edu.br.
} 


\section{INTRODUÇÃO}

Muitas são as leituras possíveis para Ouro de tolo (1973), de Raul Seixas. Para alguns, a canção foi um grito de protesto contra o discurso ufanista e triunfalista do regime militar, apoiado, então, na retórica do "Milagre econômico" (BOSCATO, 2006, p. 152). Na opinião de outros, ao fazer alusão aos falsos alquimistas que, na Idade Média, asseveravam ser possível obter ouro a partir do chumbo, o compositor quis atentar para a elevação espiritual do homem (do estado pesado - chumbo - para o leve, - ouro) com base na observação de sua realidade (id., p. 153). Sabemos que a poesia abre a janela das diversas leituras, e, por isso, encontramos, nessa canção, levando em consideração não somente a letra, mas também a melodia, a harmonia e a cadência, um paralelo possível com alguns dos mais célebres aforismos de Friedrich Nietzsche.

Inicialmente, encontrar pontos de contato entre o cantor e o filósofo não parece ser tarefa difícil e/ou inédita: os questionamentos de Nietzsche quanto à forma tradicional de pensar, e, principalmente, acerca das questões morais advindas do judaísmo e cristianismo, que para ele eram limitadoras da ação humana (PERCY, 2011, p. 5), foram basilares no delineamento da contracultura, movimento cuja bandeira Raul Seixas ajudou a hastear em terras brasileiras. Embora os ideais do autor de Para além do bem e do mal (1886) e Genealogia da Moral (1887) fossem mais focados no indivíduo, o período do pós-guerra aliou suas assertivas às experimentações místicas e experiências comunitárias, criando uma ponte possível entre seu pessimismo e a revolução cultural incipiente.

Theodore Roszak (1972) foi um dos pensadores responsáveis pela elucidação de tal elo: ele definiu a contracultura como um movimento de jovens interessados pela psicologia da alienação, misticismo oriental, drogas psicodélicas e experiências comunitárias, cuja concepção era absolutamente oposta aos valores e pressupostos que constituíam os pilares da sociedade de então.

Corriam os anos 60 e um novo estilo de mobilização e contestação social, bastante diferente da prática política da esquerda tradicional, firmava-se cada vez com maior força, pegando a crítica e o próprio Sistema de surpresa e transformando a juventude, enquanto grupo, num novo foco de contestação radical. [...] Começavam a se delinear, assim, os contornos de um movimento social de caráter fortemente libertário, com enorme apelo junto a uma juventude de camadas médias urbanas e com uma prática e um ideário que colocavam em xeque, frontalmente, alguns valores centrais da cultura ocidental, especialmente certos aspectos essenciais da racionalidade veiculada e privilegiada por esta mesma cultura. (PEREIRA, 1986, p.7).

As oposições que passavam a subir ao palco da vida nessa época - o horror ao velho e exaltação do novo, a imaginação em detrimento da realidade, o oprimido denunciando o opressor, as convicções cedendo seu outrora lugar de honra aos experimentalismos e a pretensa derrocada dos valores e instituições que regularam as vidas das pessoas até então - foram embaladas, principalmente, pelo rock, estilo 
musical que se metamorfoseou no decorrer da década de 50 e passou a ser rotulado como um estilo "feito por jovens para jovens". Na esteira desses acontecimentos, a cena brasileira deparava-se, no início dos anos 70, com a decepção dos governos democráticos que não teve (e nem embrionários foram), e com a falta de perspectivas dentro do regime autoritário sob o qual estava.

\begin{abstract}
Raul Seixas contribuiu para uma crítica ao conformismo e às visões de mundo fechadas que não admitem explicações outras a não ser as que a sua determinada religião, moral, visão científica ou política apregoam. Mas a sua crítica não era somente uma negação niilista: também era a afirmação de que formas de Espiritualidade libertárias e humanizadas seriam possíveis. (BOSCATO, 2006, p. 46).
\end{abstract}

Assim, vemos no cantor brasileiro não somente o descontentamento, mas, principalmente, uma tendência à ruptura, apregoando uma nova forma de ver, viver e pensar o mundo. E é nesse estabelecimento de um novo padrão de valores, considerando não haver no homem formas inatas de bem e mal, verdade e mentira ou belo e feio, mas apenas o desejo de poder suprimido pela humildade, submissão e foco no além em detrimento do presente - contribuição judaico-cristã - que se pavimenta o caminho que leva Nietzsche ao imaginário e intelecto de diversos questionadores da ordem, em especial daqueles que, de uma forma ou outra, viveram experiências frustrantes com as religiões tradicionais. Com Raul Seixas, não foi diferente: inspirado por novas experimentações místicas, formas de culto e pregando a plena liberdade individual, o músico participou e divulgou insistentemente a "Sociedade Alternativa", sob o slogan "Faça o que tu queres pois é tudo da lei" (CARMO, 2000, p. 114).

Há dois pontos interessantes e de observação obrigatória que nos servirão de linha condutora: o primeiro diz respeito ao transcendentalismo de ambos os autores; o segundo, ao pessimismo que os dizeres e relatos de ambos trazem à tona. Em se levando em conta o primeiro, vemos emergir da filosofia o autodeclarado ateu que soube ler na "morte de Deus" o sintoma principal de sua época: a influência da religião diminuía constantemente na vida das pessoas, ao passo que mudavam o cerne de suas preocupações da metafísica para o cotidiano e passavam a se sentirem desprotegidas e escravizadas, por não mais poderem contar com o pai bondoso que controlava os acontecimentos e ditava suas regras de comportamento. Não enxergando mais a presença de Deus, os contemporâneos de Nietzsche não mais precisavam dele, e, assim, todos os valores e verdades que apregoavam em seu nome tornavam-se um empecilho à existência.

O homem louco se lançou para o meio deles e trespassou-os com seu olhar. 'Para onde foi Deus', gritou ele, 'já Ihes direi! Nós o matamos vocês e eu. Somos todos seus assassinos! Mas como fizemos isso? Como conseguimos beber inteiramente o mar? Quem nos deu a esponja para apagar o horizonte? Que fizemos nós, ao desatar a terra do seu sol? Para onde se move agora? Para onde nos movemos nós? Para longe de todos os sóis? Não caímos continuamente? Para trás, para os lados, para a frente, em todas as direções? Existem ainda 'em cima' e 'embaixo'? Não vagamos como que através de um nada 
infinito? Não sentimos na pele o sopro do vácuo? Não se tornou ele mais frio? Não anoitece eternamente? Não temos que acender lanternas de manhã?' [...] Como nos consolar, a nós assassinos entre os assassinos? O mais forte e mais sagrado que o mundo até então possuíra sangrou inteiro sob os nossos punhais - quem nos limpará este sangue? Com que água poderíamos nos lavar? Que ritos expiatórios, que jogos sagrados teremos de inventar? A grandeza desse ato não é demasiado grande para nós? Não deveríamos nós mesmos nos tornar deuses, para ao menos parecer dignos dele? Nunca houve um ato maior - e quem vier depois de nós pertencerá, por causa desse ato, a uma história mais elevada que toda a história até então. (NIETZSCHE, 2012, p. 125).

Da música, aquele que sempre se declarou agnóstico e foi simpático às novas experiências de culto, pertenceu a uma geração que pôs em cheque os valores espirituais norteadores da vida do Ocidente, mas, talvez, por querer perpetrar um ataque às religiões majoritárias do que por questionar fé em si. "Raul Seixas não era antirreligioso, mas 'multirreligoso', constantemente inquieto, impressionado com o mistério da vida e consciente da existência de uma fonte de sentido além dessa instância em que vivemos" (CALVANI, 1998, p. 214). Deus era assunto recorrente em suas letras, afinal, em suas próprias palavras, "é o que me falta para compreender o que não compreendo" (BOSCATO, 2006, p. 12). Tal relação pode ser bem compreendida ao analisarmos os trechos das músicas DDI (1983) e Paranóia (1975):

Alô, aqui é do céu / Quem tá na linha é Deus / Tô vendo tudo esquisito / O que que há com vocês? / Por favor, não deixem a peteca cair / Que o diabo diz que vai baixar de uma vez por aí / Eu fiz vocês como eu / Imagem e perfeição / E vocês anarquizando /A minha reputação / Não é só novena, terço e oração / Em vez de resmungar eu quero é ver / Vocês em ação / Vocês em ação! / Foram milhões de anos dedicado a vocês / Fazendo vossas cabeças, não fui eu quem marquei / O que que vocês querem exigir mais de mim / Se tudo o que eu faço vocês acham ruim

Quando esqueço a hora de dormir / E de repente chega o amanhecer / Sinto a culpa que eu não sei de que / Pergunto o que que eu fiz? / Meu coração não diz e eu... / Eu sinto medo! / Eu sinto medo! / Se eu vejo um papel qualquer no chão / Tremo, corro e apanho pra esconder / Com medo de ter sido uma anotação que eu fiz / Que não se possa ler / E eu gosto de escrever, mas... / Mas eu sinto medo! / Eu sinto medo! / Tinha tanto medo de sair da cama à noite pro banheiro / Medo de saber que não estava ali sozinho porque sempre... / Sempre... sempre... / Eu estava com Deus! / Eu estava com Deus! / Eu estava com Deus! / Eu tava sempre com Deus! / Minha mãe me disse há tempo atrás / Onde você for Deus vai atrás / Deus vê sempre tudo que cê faz / Mas eu não via Deus / Achava assombração, mas... / Mas eu tinha medo! / Eu tinha medo! / Vacilava sempre a ficar nu lá no chuveiro, com vergonha / Com vergonha de saber que tinha alguém ali comigo / Vendo fazer tudo que se faz dentro dum banheiro / Vendo fazer tudo que se faz dentro dum banheiro / Para...nóia / Dedico esta canção: / Paranóia! / Com amor e com medo (com amor e com medo) / Com amor e com medo (com amor e com medo)

Quanto ao segundo - o pessimismo -, temos que, observando a distância entre o mundo real em que seus contemporâneos viviam e o ideal no qual acreditavam, 0 
pensador alemão soube ler, na vontade e paixões humanas, o oposto da felicidade. Para ele, enquanto o homem não conseguisse se livrar delas, estaria condenado à infelicidade e a levar a vida seguindo regras impostas a partir da desilusão. Por isso, o pessimismo, a inveja e as proibições são traços tão marcantes da sociedade de sua época, da nossa e, segundo ele, de todas as demais.

\begin{abstract}
Essa moral heterônoma, imposta, escolhida pelos dominadores, imposta pelo passado e predominante no presente pela vontade dos que representam os interesses do passado, é odiosa para mim. Quis substituir o "tu deves" pelo "eu quero". O homem não é homem enquanto não puder praticar esse grande ato de liberdade, que o tornará senhor de si, quando respeitará a dignidade alheia por amor à sua própria dignidade, e assim o fará porque quer e não porque deve. (NIETZSCHE, 2013, p. 33).
\end{abstract}

E o cantautor não fica para trás nesse quesito. Revisitando frequentemente a temática social, coloca-a como um pano de fundo determinante da ação principal, na qual os homens acabam sempre por lidar com seus impedimentos. De acordo com Raul Seixas, não era possível dissociar o homem de seu meio ou mesmo dos outros homens, sendo a época em que iniciou sua carreira - o princípio dos anos 70 - um tempo em que a frustração, o medo e a desesperança podiam ser cantados por todos os indivíduos. Por isso, conforme Jorge (2012), a importância conferida por ele ao pronome "eu" e ao verbo "ser", atestando a tomada de consciência a respeito de si e dos demais.

A verdade é prenúncio de um momento, o caos é prenúncio de um momento. Quando eu digo que sou a luz das estrelas, não estou falando de mim. O pedreiro lá da frente de casa, que está construindo um edifício, canta essa música como se fosse ele. Isso porque nós somos o verbo ser. Sendo o que você tem a vontade de ser, não existe mais nada. Nós somos, e está acabado. Tudo é, então, o eu é fortíssimo. Você tem de ter primeiro a consciência do eu para poder respeitar a terceiros e então fazer o que quer, que é tudo da lei, da sua lei. (SEIXAS apud PASSOS, 1993, p. 107).

Assim, considerando a realidade, a desilusão, o sonho e o apego ao transcendental, propomos que, na negação do que é larga e quase indiscutivelmente considerado felicidade que reside um ponto de contato entre Raul Seixas e Nietzsche. $E$ isso nos remete ao objetivo visado neste estudo; ou seja, constatada a afinação do possível contato e de suas implicações, poderíamos refletir sobre alguns pontos abordados por tais autores e, dessa maneira, colocá-los em diálogo.

\title{
2. DESENVOLVIMENTO
}

\subsection{Letra e música: desconstruindo as alegrias}

Avaliando a composição de Raul Seixas, lembramo-nos de que se uma "[...] forma de apreciação empírica da canção é a identificação dos estribilhos e dos mecanismos de reiteração." (TATIT, 1997, p. 101), o que é conseguido com Ouro de tolo é a ampliação do modo de "apreensão empírica do ouvinte". Em um narrar abrupto dos 
lamentos que afloram frente à incompletude que as conquistas oferecem, temos a repetição não de estrofes maiores - ou refrões - mas de excertos relacionados às marcas populares que o sucesso proporciona, trazendo um efeito prolongado à lamentação cantada e abarcando um sentimento de insatisfação que percorre as conquistas pessoais, o sucesso financeiro, o direito ao lazer e as perspectivas para o futuro.

Essa romantização das não-conquistas em diferentes composições artísticas comumente é marcada por uma produção oposta à percebida em Ouro de tolo. Nas letras de certos sambas, por exemplo, além do ritmo acalentado, o canto de esperança, aqui entendido como a idealização ou a utopia, adota como marcação os adjetivos e melodias mais pausadas do que a observada na canção em discussão. Paulinho da Viola, em Dança da solidão (1972), cantando o amor e um dos possíveis efeitos sentidos após a sua desconstrução, descreve a solidão numa toada daquele que dela compartilha; isto é, suavemente. No veio da não consumação daquilo que era pretendido, compreendemos que o cantar pausado, as tentativas de definição e a construção textual que nos remetem a um mantra e aproximam aqueles que sofrem o mesmo dissabor: público/ouvinte e eu-lírico.

Solidão é lava / Que cobre tudo / Amargura em minha boca / Sorri seus dentes de chumbo... / Solidão, palavra / Cavada no coração / Resignado e mudo / No compasso da desilusão... / Viu! / Desilusão, desilusão / Danço eu, dança você / Na dança da solidão... / Desilusão, desilusão / Danço eu, dança você / Na dança da solidão... / Camélia ficou viúva, / Joana se apaixonou, / Maria tentou a morte, / Por causa do seu amor... / Meu pai sempre me dizia: / Meu filho tome cuidado, / Quando eu penso no futuro, / Não esqueço o meu passado / Oh!... / Desilusão, desilusão / Danço eu, dança você / Na dança da solidão / Viu! / Desilusão, desilusão / Danço eu, dança você / Na dança da solidão / Viu! / Quando vem a madrugada / Meu pensamento vagueia / Corro os dedos na viola / Contemplando a lua cheia... / Apesar de tudo existe / Uma fonte de água pura / Quem beber daquela água / Não terá mais amargura / Oh!... / Desilusão, desilusão / Danço eu, dança você / $\mathrm{Na}$ dança da solidão / Viu! / Desilusão, desilusão / Danço eu, dança você / Na dança da solidão / Viu! / Desilusão, desilusão / Danço eu, dança você / Na dança da solidão / Viu!

Ao nos determos no aspecto visual - texto verbal - e sonoro da canção de Raul Seixas, percebemos certos efeitos acarretados pela reiteração de períodos semelhantes nos seus aspectos sintático-semânticos, assim como pelo modelo de execução melódica das diversas estrofes. Em outras palavras, identificamos construções frasais de cunho perlocutório, que não necessitam de descrições e definições dos sentimentos a fim de que sejam aproximados eu-lírico e público. Fundamental, ainda, é o preenchimento na melodia, em boa parte dos compassos, por palavras e não pelo silêncio, como no exemplo de Dança da solidão.

Toda inflexão da voz [...] acrescida de um prolongamento das durações, desperta tensão pelo próprio esforço fisiológico da emissão. Esta tensão física corresponde, quase sempre, a uma tensão emotiva e o ouvinte já está habituado a ouvir a voz do cantor em alta frequência 
relatando casos amorosos, onde há alguma perda ou separação que gera um grau de tensão compatível. (TATIT, 1997, p. 101).

Por meio de construção textual de sequências predominantemente argumentativas, observadas ao menos em seis estrofes, o público é levado a compreender as infelicidades na leitura de façanhas que nos remetem a um quadro contrário ao cantado. Raul Seixas vai de encontro, com seu estilo marcadamente rebelde e focado na crítica social, ao antigo "pão e circo", ou seja, canta em tom lamurioso as pretensas vitórias e mostra-se convicto de sua insatisfação e inquieto com sua - para os outros, injustificada - angústia. O sucesso profissional, financeiro e as diversas opções de lazer são desprezados pelo autor-intérprete em nome de uma esperança que não está confinada ao tempo e espaço em que vive. Nesse contexto, o verbo dever, conjugado no pretérito imperfeito, assume a função do estribilho de outras odes e de mecanismos já descritos acima.

A política do Pão e circo [...] era o modo com o qual os líderes romanos lidavam com a população em geral, para mantê-la fiel à ordem estabelecida e conquistar o seu apoio. Esta frase tem origem na Sátira $X$ do humorista e poeta romano Juvenal (vivo por volta do ano 100 d.C.) e no seu contexto original, criticava a falta de informação do povo romano, que não tinha qualquer interesse em assuntos políticos, e só se preocupava com o alimento e o divertimento.

Com a sua gradual expansão, o Império Romano tornou-se um estado rico, cosmopolita, e sua capital, Roma, tornou-se o centro de praticamente todos os acontecimentos sociais, políticos e culturais na época de seu auge. Isso fez naturalmente com que a cidade se expandisse, com gente vindo das mais diferentes regiões em busca de uma vida melhor. Como acontece até hoje em qualquer parte do mundo, pessoas humildes e de poucas condições financeiras iam se acotovelando nas periferias de Roma, em habitações com conforto mínimo, espaço reduzido, de pouco ou nenhum saneamento básico, e que eram exploradas em empregos de muito trabalho braçal e pouco retorno financeiro.

Esses ingredientes, em qualquer sociedade são perfeitos para detonarem revoltas sociais de grandes dimensões. Para evitar isso, os imperadores optaram por uma solução paliativa, que envolvia a distribuição de cereais, e a promoção de vários eventos para entreter e distrair o povo dos problemas mais sérios na fundação da sociedade romana. (SANTIAGO, 2012)

Tornando ao que consideramos fundamental quanto ao aspecto sonoro, a maneira como se dá a forma melódica ao longo da canção poderia ser considerada uma tentativa de desvalorização do que foi logrado. Posto isto, fica a cargo do ouvinte/público perceber que os espaços de prolongamento das notas e os poucos momentos de silêncio denotam que as inúmeras conquistas são insuficientes para o preenchimento da insatisfação, fato que, paradoxalmente, leva-nos a constatar. Em síntese, entendemos que a reiteração se faz pelo verbo dever, abordado anteriormente, acrescido de certos triunfos que desenham uma imagem do ato de "vencer na vida". 
Trata-se também de um dispositivo de gramática melódica, fundamental para a retenção da memória e para as faculdades de previsão que esse tipo de linguagem exige. A reiteração torna significativo o fluxo inexorável do tempo. Basta um ligeiro apuro musical do ouvido para se depreender reiterações. (TATIT, 1997, p. 101).

Prolongando-nos na relação melodia e letra, o tratamento dado às interjeições na interpretação de Raul Seixas distingue dois momentos distintos da letra da canção. Tal marcação ocorre pelo efeito mais longo no momento de monólogo; nesse, o sujeito apresenta um sentimento de consternação com sua própria índole que em nada encontra a diversão incrustrada. Dessa forma, a entonação utilizada poderia ser descrita como uma tentativa lastimosa, de lamúria: "[...] Ah! / Mas que sujeito chato sou eu / Que não acha nada engraçado / Macaco, praia, carro, jornal, tobogã / Eu acho tudo isso um saco" (RAUL SEIXAS, 1973).

Conforme atesta Tatit (1997, p. 119), "O prolongamento das durações, por sua vez, tem como corolário a desaceleração rítmica e o abrandamento da pulsação, substituindo os efeitos somáticos por efeitos psíquicos geralmente ligados a conteúdos afetivos."

Noutra estrofe em que se faz presente a interjeição, a marcação de um posicionamento que não o de abatimento se dá pela impostação de voz não afinada à descrita acima. Caracterizada pelo aspecto vivaz, assim como pelo não prolongamento empreendido da nota, a interjeição introduz uma ação que será tomada pelo eu lírico que intenta não se entregar para o fim da vida: "[...] Ah! / Eu é que não me sento / No trono de um apartamento / Com a boca escancarada / Cheia de dentes / Esperando a morte chegar" (RAUL SEIXAS, 1973).

Desse modo, a longa letra de Ouro de tolo, combinada à melodia que não permite pausas e ao tom lamurioso de sua interpretação, vem atingir-nos possivelmente em nossas principais fraquezas: ao revelar-se portador de tudo aquilo que seria, para muitos, a quintessência de toda uma vida de trabalho, o supra-sumo dos esforços e o ponto alto da felicidade -

[...] porque eu tenho um emprego / Sou o dito cidadão respeitável e ganho quatro mil cruzeiros por mês / Eu devia agradecer ao Senhor / Por ter tido sucesso na vida como artista / [...] porque consegui comprar um Corcel 73 / [...] por morar em Ipanema / [...] Eu devia estar sorrindo e orgulhoso por ter finalmente vencido na vida / [...] Eu devia estar contente por ter conseguido tudo o que eu quis / Mas confesso, abestalhado, que eu estou decepcionado [...]" (id., 1973).

- o cantor mostra-se, ao mesmo tempo, desiludido, convicto de sua insatisfação e inquieto. Combinando tudo isso, Raul Seixas abriu-nos o leque de uma série de análises possíveis, convidando-nos a proceder a análise, utilizando mais uma vez um tom autobiográfico. Em As aventuras de Raul Seixas na cidade de Thor (1974), cantou: “[...] 
Quando eu compus fiz Ouro de tolo / Uns imbecis me chamaram de Profeta do Apocalipse / Mas eles só vão entender o que eu falei / No esperado dia do eclipse."

\subsection{Aforismos}

Em 2011, Allan Percy, especialista em coaching e em desenvolvimento pessoal e autor de livros de auto-ajuda, lançou o livro Nietzsche para estressados: 99 doses de filosofia para despertar a mente e combater as preocupações. Não é fácil, principalmente para quem se encontra na academia, acompanhar o pensamento do célebre filósofo alemão adentrar ao efervescente mercado da auto-ajuda, sendo avaliado e comentado por um autor que não pertence aos círculos das letras, das artes ou da filosofia. No entanto, o autor-palestrante, também conhecido por títulos como Oscar Wilde para inquietos: 99 máximas de um dos maiores gênios da literatura para viver com autenticidade e paixão (2012) e Kafka para sobrecarregados: 99 pílulas de sabedoria para lidar com a loucura do dia a dia (2012), revela-se competente tanto na pesquisa para a seleção do conteúdo de suas obras quanto na visão prática que apresenta na interpretação e aplicação das máximas trabalhadas para o dia a dia de pessoas comuns.

Essas interpretações e aplicações não são de nosso interesse no presente trabalho; todavia, aproveitaremos alguns dos aforismos compilados por Percy em nosso paralelo com a canção de Raul Seixas. Além disso, ao enxergarmos um pouco do vasto pensamento de Nietzsche em Ouro de tolo, estamos certamente fazendo o mesmo que aquele que elevou o filósofo alemão à categoria de best-seller: constatando que sua filosofia não está afastada de nosso cotidiano. Uma vez que o compositor optou pela conjugação do verbo "ser" em primeira pessoa e declarou que isso garantia à canção um caráter universal, podemos ver o pensador ecoar nas pequenas - ou grandes situações cotidianas. E, conforme posto anteriormente, que o apelo ao transcendental, o pessimismo e a insatisfação podem ser lidos no consciente (e sub) de um grande número de pessoas.

Entendemos que podemos travar um diálogo e, desse modo, construir o seguinte quadro: 
Quadro 1. Uma leitura comparativa

\begin{tabular}{|c|c|}
\hline Raul Seixas - Ouro de tolo & Nietzsche - aforismos \\
\hline Eu devia estar contente & $\begin{array}{l}\text { A potência intelectual de um homem se mede pelo } \\
\text { humor que ele é capaz de manifestar. (PERCY, } \\
2011 \text {, p. 63). }\end{array}$ \\
\hline $\begin{array}{l}\text { Porque eu tenho um emprego } \\
\text { Sou um dito cidadão respeitável } \\
\text { E ganho quatro mil cruzeiros por mês }\end{array}$ & $\begin{array}{l}\text { Você tem o seu caminho. Eu tenho o meu. O } \\
\text { caminho correto e único não existe. (ibid., p. 105). }\end{array}$ \\
\hline Eu devia agradecer ao Senhor & $\begin{array}{l}\text { Quem tem uma razão de viver é capaz de suportar } \\
\text { qualquer coisa. (ibid., p. 6). }\end{array}$ \\
\hline $\begin{array}{l}\text { Por ter tido sucesso na vida como } \\
\text { artista }\end{array}$ & $\begin{array}{l}\text { O sucesso sempre foi um grande mentiroso. (ibid., } \\
\text { p. 22). }\end{array}$ \\
\hline $\begin{array}{l}\text { Eu devia estar feliz } \\
\text { Porque consegui comprar um Corcel } \\
73\end{array}$ & $\begin{array}{l}\text { As ilusões são certamente prazeres dispendiosos, } \\
\text { mas a destruição delas é mais dispendiosa ainda. } \\
\text { (ibid., p. 84). }\end{array}$ \\
\hline $\begin{array}{l}\text { Eu devia estar alegre e satisfeito } \\
\text { Por morar em Ipanema }\end{array}$ & $\begin{array}{l}\text { São muitas as verdades e, por esse motivo, não } \\
\text { existe verdade alguma. (ibid., p. 44). }\end{array}$ \\
\hline $\begin{array}{l}\text { Depois de ter passado fome por dois } \\
\text { anos } \\
\text { Aqui na Cidade Maravilhosa }\end{array}$ & $\begin{array}{l}\text { Quantos homens sabem observar? E, desses } \\
\text { poucos que sabem, quantos observam a si } \\
\text { próprios? "Cada pessoa é o ser mais distante de si } \\
\text { mesmo." (ibid., p. 94). }\end{array}$ \\
\hline & $\begin{array}{l}\text { A mentira mais comum é a que o homem usa para } \\
\text { enganar a si mesmo. (ibid., p. } 45 \text { ). }\end{array}$ \\
\hline
\end{tabular}




\begin{tabular}{|c|c|}
\hline $\begin{array}{l}\text { Ah! Eu devia estar sorrindo e } \\
\text { orgulhoso } \\
\text { Por ter finalmente vencido na vida }\end{array}$ & $\begin{array}{l}\text { O homem é, antes de tudo, um animal que julga. } \\
\text { (ibid., p. 27). }\end{array}$ \\
\hline $\begin{array}{l}\text { Mas eu acho isso uma grande piada } \\
\text { E um tanto quanto perigosa }\end{array}$ & $\begin{array}{l}\text { O homem é algo a ser superado. Ele é uma ponte, } \\
\text { não um objetivo final. (ibid., p. 23). }\end{array}$ \\
\hline $\begin{array}{l}\text { Eu devia estar contente } \\
\text { Por ter conseguido tudo o que eu quis }\end{array}$ & $\begin{array}{l}\text { Toda queixa contém em si uma agressão. (ibid., p. } \\
\text { 40). }\end{array}$ \\
\hline Mas confesso abestalhado & \\
\hline $\begin{array}{l}\text { Que eu estou decepcionado } \\
\text { Porque foi tão fácil conseguir } \\
\text { E agora eu me pergunto: E daí? }\end{array}$ & $\begin{array}{l}\text { O cérebro verdadeiramente original não é o que } \\
\text { enxerga algo novo antes de todo mundo, mas o que } \\
\text { olha para coisas velhas e conhecidas, já vistas e } \\
\text { revistas por todos, como se fossem novas. Quem } \\
\text { descobre algo é normalmente este ser sem } \\
\text { originalidade e sem cérebro chamado sorte. (ibid., } \\
\text { p. } 68 \text { ). }\end{array}$ \\
\hline & Seus maiores bens são seus sonhos. (ibid., p. 82). \\
\hline $\begin{array}{l}\text { Eu tenho uma porção de coisas } \\
\text { grandes pra conquistar, }\end{array}$ & $\begin{array}{l}\text { O homem é a causa criativa de tudo o que acontece. } \\
\text { (ibid., p. 81). }\end{array}$ \\
\hline e eu não posso ficar aí parado & Toda convicção é uma prisão. (ibid., p. 106). \\
\hline $\begin{array}{l}\text { Eu devia estar feliz pelo Senhor } \\
\text { Ter me concedido o domingo }\end{array}$ & $\begin{array}{l}\text { Nossa vida nos parece muito mais bonita quando } \\
\text { deixamos de compará-la com as dos outros. (ibid., } \\
\text { p. 107). }\end{array}$ \\
\hline
\end{tabular}


Pra ir com a família ao Jardim

Zoológico

Dar pipoca aos macacos

Ah! Mas que sujeito chato sou eu

Que não acha nada engraçado

Macaco praia, carro, jornal, tobogã

Eu acho tudo isso um saco

É você olhar no espelho

Se sentir um grandessíssimo idiota

Saber que é humano, ridículo, limitado

Que só usa dez por cento de sua

Cabeça animal

E você ainda acredita que é um doutor, padre ou policial

Que está contribuindo com sua parte

Para nosso belo quadro social

Eu que não me sento

No trono de um apartamento

Com a boca escancarada cheia de
A potência intelectual de um homem se mede pelo humor que ele é capaz de manifestar. (ibid., p. 63).

Os maiores êxitos não são os que fazem mais ruído e sim nossas horas mais silenciosas. (ibid., p. 29).

É muito difícil os homens entenderem sua ignorância no que diz respeito a eles mesmos. (ibid., p. 77).

Acredito que os animais veem o homem como um ser igual a eles que perdeu, de forma extraordinariamente perigosa, a sanidade intelectual animal. Ou seja: veem o homem como um animal irracional, um animal que sorri, que chora, um animal infeliz. (ibid., p. 74).

O homem que imagina ser completamente bom é um idiota. (ibid., p. 15).

A maneira mais eficaz de corromper o jovem é ensiná-lo a admirar aqueles que pensam como ele e não os que pensam de forma diferente. (ibid., p. 38).

Pobre do pensador que não é o jardineiro, mas apenas o canteiro de suas plantas. (ibid., p. 78). 


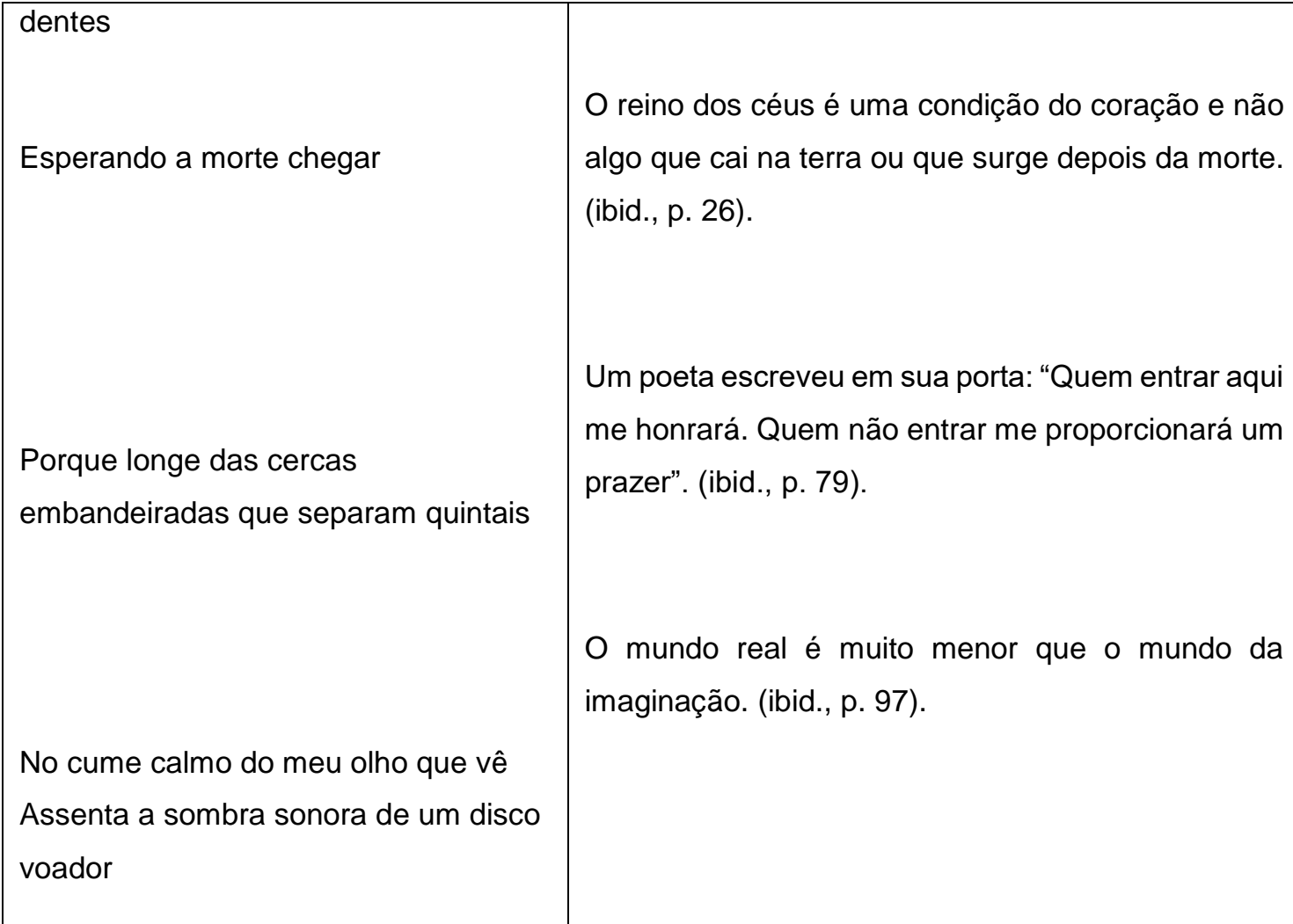

Fonte: Autores.

Ao lermos em paralelo os versos e as máximas, fica-nos claro que ambos os autores buscam para os demais ou narram de si uma espécie de "despertar da consciência": os reais valores não são os prezados por este mundo. Não podemos esquecer que há um intervalo de aproximadamente um século entre os dizeres filosóficos e a canção, portanto, não é possível atribuir a culpa apenas à sociedade consumista ou o grande e opressor apelo midiático cantados por Raul; é necessário olhar em retrospectiva e pensar que, no cotidiano em um mundo que talvez não consigamos nem imaginar como era, as mesmas questões já eram visíveis e os valores já projetados para fora - a infelicidade do cantor, com suas ilusões se desvanecendo e na expectativa de coisas maiores é bem lida pelo filósofo, que, acertadamente, assevera nas entrelinhas, que, quanto mais consciente de si e do mundo, mais perturbado e infeliz se torna o sujeito.

Destacamos, por tal viés, o fato de observarmos um intérprete que começa a se comparar aos demais - "Eu devia estar contente [...] - e um filósofo que sabe ler o descontentamento na ciência de si e do mundo: "A potência intelectual de um homem se mede pelo humor que ele é capaz de manifestar". Um cantor que busca possivelmente explicar e talvez redimir-se por sua infelicidade - "Eu devia agradecer ao Senhor / Por ter tido sucesso na vida como artista / Eu devia estar feliz / Porque consegui comprar um Corcel 73" - e um pensador que sabe que a felicidade não pode ser aceita ou manifesta dentro de padrões universais ou universalizantes: "São muitas as verdades e, por esse motivo, não existe verdade alguma". Um sujeito que toma 
consciência da incompletude de seu ser e de seu viver - "Ah! Eu devia estar sorrindo e orgulhoso / Por ter finalmente vencido na vida / Mas eu acho isso uma grande piada / $\mathrm{E}$ um tanto quanto perigosa" - e alguém que avaliza sua insatisfação por saber ler as imensas possibilidades ainda inexploradas de nossa condição humana: "A mentira mais comum é a que o homem usa para enganar a si mesmo". "O homem é algo a ser superado. Ele é uma ponte, não um objetivo final".

A confissão e o alerta do cantautor - "É você olhar no espelho / Se sentir um grandessíssimo idiota / Saber que é humano, ridículo, limitado / Que só usa dez por cento de sua / Cabeça animal" é compreendida e estimulada pelo sábio: "É muito difícil os homens entenderem sua ignorância no que diz respeito a eles mesmos". "O homem que imagina ser completamente bom é um idiota". Ao mover-se para o campo do das perspectivas - "Eu tenho uma porção de coisas grandes / Pra conquistar, / e eu não posso ficar aí parado", Raul Seixas também acha um avalista em Nietzsche: "Seus maiores bens são seus sonhos". "O homem é a causa criativa de tudo o que acontece". Finalmente, ao partir para o isolamento e narrar seu fim último - "Porque longe das cercas embandeiradas que separam quintais / No cume calmo do meu olho que vê / Assenta a sombra sonora de um disco voador", o músico mais uma vez encontra suporte no erudito: "Um poeta escreveu em sua porta: Quem entrar aqui me honrará. Quem não entrar me proporcionará um prazer."; "O mundo real é muito menor que o mundo da imaginação".

A aproximação das impressões dos autores desvenda um panorama atemporal, o que, possivelmente, soa-nos ainda mais aterrador. Nietzsche só é capaz de forjar suas premissas após profunda reflexão e constante observação do indivíduo, confinado às suas obrigações terrenas por estar inserido em um estofo social tecido com base em um apego ao material que acredita poder suplantar o abstrato; do mesmo modo, Raul Seixas, ciente de ter chegado ao topo da escalada imaginária dos bens que traduzem as alegrias, grita por uma libertação de si mesmo e dos outros com a mera visão de um lugar que não é esse, que não preza pelo que aqui se preza e que se move determinado por motivações que não as daqui. Se a inquietação puder ser considerada um passo inicial para a mudança, temos que pensador e artista visam a uma quebra de paradigmas ao cativar um público que lê suas agruras em seus escritos.

\section{CONCLUSÃO}

Desse modo, temos que a aproximação entre os dois autores visa a preencher uma lacuna que nos é imanente; se, em diferentes épocas - marcadas por problemas, motivações e valores distintos - nossa incompletude clama, podemos nos dizer vítimas de uma materialização daquilo que, em verdade, é imaterial. Traço distintivo da composição de Raul Seixas e do quadro pós-morte de Deus, pintado por Nietzsche, é o 
olhar por sobre, ou seja, o esperar pelo que não se vê. E isso nada mais é que a negação do mundo objetivo em nome de outra realidade, que se espera oposta ao que se tem.

Se perdemos nosso guia e proteção, conforme asseverou o filósofo, temos buscado nos encontrar e traduzir nossos anseios na concretude das coisas mensuráveis. Possivelmente, de acordo com o cantor, nós o consigamos fazer à medida que o "pão e o circo" consigam distrair-nos o suficiente ao ponto que nossos olhos não vejam "a sombra sonora de um disco voador". Mas, a partir do momento em que a desilusão vem à frente, doem nossos olhos ao anunciar aquilo que está no imaterial.

Filósofo e compositor trilham o mesmo caminho ao desvendar que há algo a mais. Terem sido tratados dialogicamente pela juventude de outrora é perfeitamente justificável, afinal de contas o pessimismo de Nietzsche para com a realidade objetiva atingiu ambos os lados do cérebro da geração embalada por Raul. Válido certamente é, a esta altura do trabalho, reforçar o tom espiritual - e por que não, religioso - dos anelos de ambos. Por isso podemos considerar-nos prostrados diante de um cenário no mínimo curioso: lidamos com um ateu que, além de acreditar em Deus, credita ao seu desprezo sofrido as trevas de uma geração. E ouvimos aquele que impõe uma nova Lei - "faça o que tu queres" - mas não consegue enxergar na plena liberdade que prega a felicidade que quer tanto encontrar.

Por fim, ambos parecem assumir os papéis de condutores para quem crê que, quanto mais entende a realidade à sua volta, mais desespero sente. E, assim, apontam para o céu - dando nomes diferentes ao que querem enxergar, mas crendo em um único nome para o que não mais suportam não sentir: a felicidade.

\section{REFERÊNCIAS}

BOSCATO, L. A. L. Vivendo a sociedade alternativa: Raul Seixas no panorama da contracultura jovem. 2006. 260f. Tese (Doutorado em História Social), Universidade de São Paulo, São Paulo, 2006. Disponível em:

<http://www.teses.usp.br/teses/disponiveis/8/8138/tde-06072007-110745/pt-br.php>. Acesso em 25 jun. 2017.

CALVANI, C. E. B. Teologia e MPB. São Paulo: Edições Loyola, 1998.

CARMO, P. S. Culturas da rebeldia: a juventude em questão. São Paulo: Senac, 2000.

JORGE, C. S. F. K. Raul Seixas: um produtor de mestiçagens musicais e midiáticas. 2403/2012. 233 p. Tese de doutorado em Comunicação e Semiótica, apresentada à PUC/SP, São Paulo, 2012. Disponível em:

<https://sapientia.pucsp.br/handle/handle/4375>. Acesso em 03 jul. 2017.

NIETZSCHE, F. A gaia ciência. São Paulo: Companhia das Letras, 2012. 
Genelogia da moral. São Paulo: Vozes, 2013.

PASSOS, S. (org.) Raul Seixas por ele mesmo: textos de autoria de Raul Seixas organizados postumamente. São Paulo: Martin Claret, 1993.

PERCY, A. Nietzsche para estressados: 99 doses de filosofia para despertar a mente e combater as preocupações. São Paulo: Sextante, 2011.

PEREIRA, C. A. M. O que é contracultura. São Paulo: Nova Cultural, 1986.

ROSZAK, T. A contracultura. São Paulo: Vozes, 1972.

SANTIAGO, E. Política do Pão e Circo. 2012. Disponível em:

$<$ https://www.infoescola. com/historia/politica-do-pao-e-circo/>. Acesso em: 11 jul. 2017.

SEIXAS, R. As aventuras de Raul Seixas na Cidade de Thor. Gita. Disponível em: <https://www.letras.mus.br/raul-seixas/90577/>. Acesso em: 11 jul. 2017.

DDI. Raul Seixas. Disponível em: <https://www.letras.mus.br/raulseixas/90586/>. Acesso em: 25 jun. 2017.

Ouro de tolo. Krig Ha Bandolo!. Disponível em:

<https://www.letras.mus.br/raul-seixas/48326/>. Acesso em: 25 jun. 2017.

Paranóia. Uah-Bap-Lu-Bap-Lah-Béin-Bum!. Disponível em:

<https://www.letras.mus.br/raul-seixas/103212/>. Acesso em: 25 jun. 2017.

TATIT, L. Musicando a semiótica: ensaios. São Paulo: Annablume, 1997.

VIOLA, P. da. Dança da solidão. Dança da solidão. Disponível em:

<https://www.letras.mus.br/marisa-monte/47277/>. Acesso em: 25 jun. 2017. 